\title{
Pemetaan Fasies Vulkanik berdasarkan Geomorfologi dan Stratigrafi Batuan Gunungapi pada Gunungapi Sindoro, Jawa Tengah
}

\author{
Jundiya Al Haqiqi ${ }^{1}$, Tri Winarno ${ }^{1}$, Jenian Marin ${ }^{1 *}$ \\ ${ }^{1}$ Departemen Teknik Geologi, Fakultas Teknik, Universitas Diponegoro, Semarang
}

\begin{abstract}
Abstrak
Gunungapi Sindoro merupakan salah satu gunungapi aktif yang berada di Provinsi Jawa Tengah dan termasuk ke dalam jajaran gunungapi Kuarter di Pulau Jawa. Aktivitas vulkanisme Gunungapi Sindoro dapat dipelajari dari aspek vulkanostratigrafinya. Penelitian ini bertujuan untuk mengidentifikasi fasies vulkanik Gunungapi Sindoro berdasarkan aspek geomorfologi dan stratigrafi batuan gunungapi. Pemetaan fasies vulkanik dilakukan dengan analisis peta dan citra satelit, observasi lapangan, dan analisis petrografi. Geomorfologi daerah penelitian diklasifikasikan menjadi 13 satuan berdasarkan aspek genetiknya, mencakup kerucut utama, kerucut parasiter, punggungan aliran lava dan piroklastik, serta dataran antargunungapi. Litologi daerah penelitian dikelompokkan menjadi 22 satuan berumur Kuarter, terutama berupa endapan jatuhan freatik, kubah lava, aliran lava, endapan jatuhan piroklastik dan endapan aliran piroklastik. Satuan vulkanostratigrafi diklasifikasikan ke dalam Khuluk Sindoro yang terdiri atas Gumuk Kembang, Gumuk Kekep dan Gumuk Watu. Khuluk Sindoro juga termasuk ke dalam Bregada Sindoro-Sumbing. Berdasarkan sejarah dan endapan vulkanik yang ditemukan, dapat diinterpretasikan bahwa karakter letusan Gunungapi Sindoro didominasi oleh letusan tipe Strombolian.Berdasarkan geomorfologi dan stratigrafi, Gunung Sindoro dibedakan menjadi 9 fasies vulkanik meliputi Fasies Sentral Sindoro, Fasies Sentral Kembang, Fasies Sentral Kekep, Fasies Sentral Watu, Fasies Proksimal Sindoro, Fasies Proksimal Kembang, Fasies Proksimal Kekep, Fasies Proksimal Watu, dan Fasies Medial Sindoro.
\end{abstract}

Kata kunci: Fasies gunungapi; Gunung Sindoro; vulkanostratigrafi.

\begin{abstract}
Sindoro Volcano is one of the active volcanoes in Central Java Province and belongs to the Java Quaternary Volcanic Chain. The volcanic activity of Sindoro Volcano can be studied from its volcanostratigraphic aspects. This study aims to identify the volcanic facies of Sindoro Volcano based on geomorphological aspects and volcanic rock stratigraphy. Volcanic facies mapping is carried out by analysis of maps and satellite imagery, field observations, and petrographic analysis. The geomorphology of the study area is classified into 13 units based on their genetic aspects, including the main cone, parasitic cone, lava ridge and pyroclastic ridge, and intermontane plain. Lithologies are grouped into 22 Quaternary units, mainly are phreatic fall deposits, lava domes, lava flows, pyroclastic fall deposits and pyroclastic flows deposits. Volcanostratigraphy units are classified into Sindoro Crown consisting of Kembang Hummock, Kekep Hummock, and Watu Hummock. Sindoro Crown is also part of Sindoro-Sumbing Brigade. Based on history and volcanic deposits found, it can be interpreted that the character of the Sindoro Volcanic eruption is dominated by Strombolian eruptions. Based on geomorphology and stratigraphy, Study area is divided into 9 volcanic facies including Sindoro Central Fasies, Kembang Central Fasies, Kekep Central Fasies, Watu Central Facies, Sindoro Proximal Facies, Kembang Proximal Facies, Kekep Proximal Facies, Watu Proximal Facies, and Sindoro Medial Facies.
\end{abstract}

Keywords: Volcanic facies; Sindoro Volcano; volcanostratigraphy.

\section{PENDAHULUAN}

Gunungapi Sindoro merupakan salah satu gunungapi aktif yang berada di Provinsi Jawa Tengah. Gunungapi Sindoro memiliki elevasi \pm
3.150,7 mdpl (meter di atas permukaan laut). Letak dari Gunungapi Sindoro itu sendiri berdekatan dengan Gunungapi Sumbing (3371 mdpl) dan Gunungapi Dieng. Ketiga gunung

*) Korespondensi: jenianmarin@gmail.com 
tersebut memiliki karakteristik yang hampir sama. Letaknya yang relatif berdekatan sangat berpengaruh terhadap batuan/ endapan yang terbentuk. Pusat Vulkanologi dan Mitigasi Bencana Geologi (2014) menyebutkan bahwa Gunungapi Sindoro memiliki catatan letusan terakhir pada 1971 dan 2011.

Aktivitas vulkanisme Gunungapi Sindoro di masa lalu tersebut menghasilkan tatanan geologi gunungapi yang menarik untuk diteliti. Salah satunya adalah stratigrafi gunungapi atau yang sering disebut sebagai vulkanostratigrafi. Stratigrafi gunungapi merupakan ilmu yang membahas urutan batuan/ endapan hasil kegiatan vulkanik suatu gunungapi. Satuan stratigrafi gunungapi dikelompokkan berdasarkan sumber, jenis batuan/endapan, serta urutan kejadian. Sandi Stratigrafi Indonesia (Ikatan Ahli Geologi Indonesia, 1996) menyebutkan penyusunan stratigrafi gunungapi dimaksudkan untuk mengkorelasikan batuan/ endapan gunungapi berdasarkan urutan kejadiannya agar evolusi pembentukan gunungapi dapat dimengerti. Penelitian mengenai vulkanostratigrafi diperlukan untuk mengetahui fasies vulkanik dan sejarah geologi gunungapi. Penelitian tersebut dapat dilakukan dengan pemeriksaan lapangan, analisis citra satelit maupun citra DEM untuk mengetahui urutan batuan/ endapan hasil kegiatan vulkanik, sehingga fasies vulkanik dan karakter letusannya dapat diketahui. Penelitian mengenai geologi gunungapi yang berkaitan dengan stratigrafi gunungapi dapat menghasilkan informasi untuk mengetahui potensi sumber daya alam yang ada serta sebagai acuan dalam mitigasi bencana gunungapi.

\section{Geologi Regional}

Pulau Jawa tempat Gunung Sindoro terletak di sebelah utara zona tumbukan antara Lempeng Eurasia dengan Lempeng Samudera IndoAustralia (Hamilton, 1979). Hal tersebut mengakibatkan, Pulau Jawa memiliki banyak rangkaian gunungapi aktif. Menurut Atmadja dkk. (1994), tumbukan ini membentuk jalur magmatisme Kuarter di Pulau Jawa yang saat memiliki banyak gunungapi aktif. Secara fisiografi, daerah penelitian termasuk ke dalam Zona Gunungapi Kuarter (van Bemmelen, 1970). Zona ini memanjang dari sisi barat hingga timur Pulau Jawa dan terbentuk dari hasil endapan gunungapi berumur Kuarter. Di Jawa Tengah sendiri, posisi Gunung Sindoro berdekatan dengan gunungapi Kuarter lainnya, yaitu Gunung Sumbing dan Kompleks Dieng (Gambar 1).

Berdasarkan stratigrafi regional, Gunung Sindoro tersusun oleh formasi dari tua ke muda sebagai berikut:

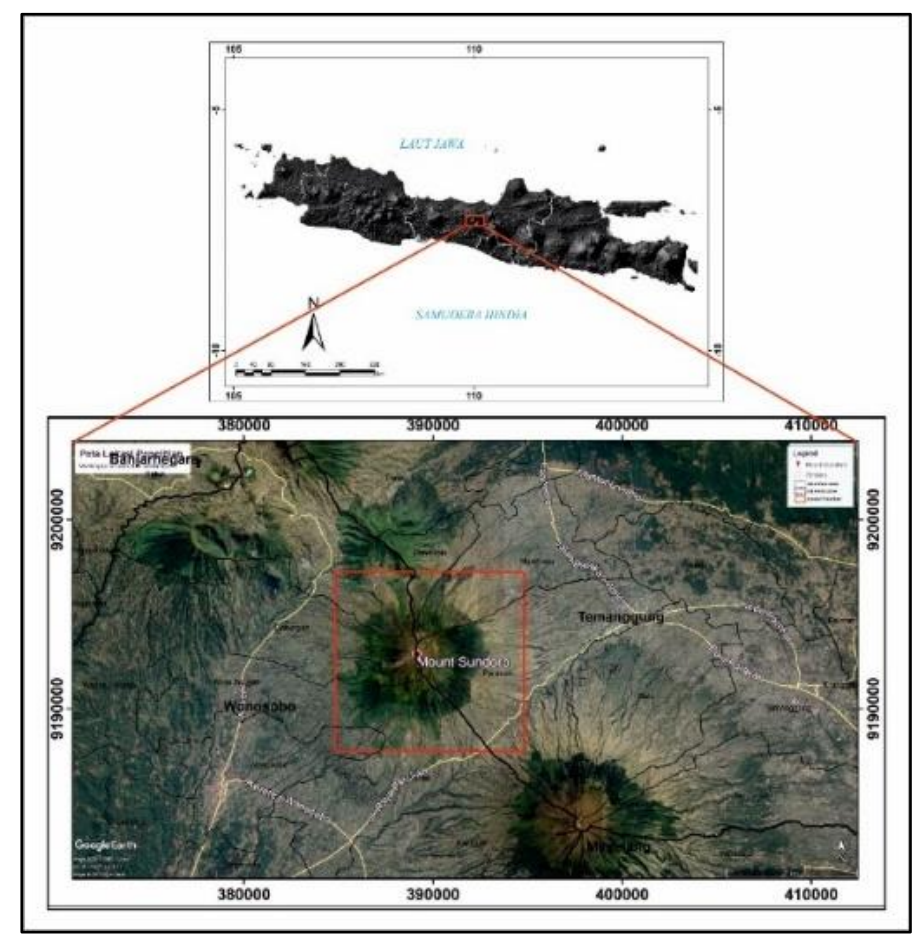

Gambar 1. Lokasi Penelitian Gunung Sindoro yang terletak di Provinsi Jawa Tengah, sederet dengan Gunung Sumbing dan Kompleks Dieng. 
1. Batuan Gunungapi Jembangan (Qj)

Lava andesit dan batuan klastika gunungapi. Terutama andesit hipersten-augit; setempat mengandung hornblende dan juga basal olivin. Selain aliran lava, terdapat breksi aliran dan piroklastik, dan lahar.

2. Batuan Gunungapi Sumbing (Qsm)

Berupa lava andesit augit-olivin, breksi aliran, breksi piroklastik dan lahar.

3. Batuan Gunungapi Sindoro (Qsu)

Lava andesit hipersten-augit dan basal olivin-augit, breksi aliran, breksi piroklastik, dan lahar. (Qso - batuan dari kerucut gunungapi permulaan, yang sebagian telah tertimbun; Qsun - dari kerucut utama gunungapi; Qsuy - terutama aliran lava dari kerucut gunungapi samping).

\section{METODOLOGI}

Citra DEM SRTM resolusi $30 \mathrm{~m}$ digunakan untuk menyusun peta topografi dasar. Dari peta topografi yang diekstrak dari data DEM ini, ditentukan cakupan lokasi penelitian, analisis pola kelurusan, dan pola penyaluran. Analisis citra satelit dari Landsat- 8 dengan resolusi $30 \mathrm{~m}$ dilakukan untuk menginterpretasi geomorfologi. Satuan geomorfologi dibedakan secara visual, sedangkan dari DEM SRTM dapat dibedakan baik visual maupun aspek kelerengannya. Analisis ini juga digunakan untuk membantu menentukan penarikan batas satuan litologi daerah penelitian.

Observasi lapangan dilakukan untuk mengamati secara langsung kondisi geologi dan mengkonfirmasi kondisi yang diinterpretasi melalui analisis citra satelit. Pengambilan sampel sayatan tipis batuan Gunung Sindoro dilakukan untuk menentukan mineralogi, dan dipilih untuk mewakili jenis batuan yang berbeda. Urutan stratigrafi batuan ditentukan melalui analisis morfostratigrafi dengan citra, diperkuat dengan pengamatan hubungan stratigrafi dan kontak di lapangan. Berdasarkan aspek geomorfologi dan stratigrafi yang diamati dari analisis citra satelit, pengamatan lapangan, dan analisis petrografi, dapat ditentukan fasies vulkanik Gunung Sindoro.

\section{HASIL}

\section{Geomorfologi Daerah Penelitian}

Secara umum, morfologi yang ditemukan di daerah penelitian berupa gunungapi, perbukitan, lembah dan dataran. Berdasarkan klasifikasi Bentuk Muka Bumi (Brahmantyo dan Bandono, 2006), daerah penelitian dapat diklasifikasikan ke dalam bentang alam pegunungan gunungapi. Ciri khas dari morfologi bentang alam ini adalah adanya bentuk-bentuk melingkar yang dapat diinterpretasikan sebagai pusat aktivitas gunungapi di daerah penelitian. Aktivitas tersebut akan membentuk morfologi seperti kerucut gunungapi, kubah lava maupun kawah seperti yang terlihat pada citra daerah penelitian. Secara genetik, terdapat 13 satuan geomorfologi di daerah penelitian (Gambar 2). Setiap satuan memiliki karakteristik geomorfologi yang khas baik dari relief, bentuk, dan litologi penyusunnya (Gambar 3). Kenampakan kerucut utama dan kerucut parasiter dapat diamati pada Gambar 4, sedangkan morfologi punggungan dapat dilihat pada Gambar 5.

\section{Stratigrafi Daerah Penelitian}

Stratigrafi daerah penelitian dapat dibagi menjadi 22 satuan batuan yang dapat dilihat dari peta geologi (Gambar 8) dan kenampakan di permukaan (Gambar 9). Secara umum, karakteristik gunungapi berciri andesit basaltik. Mineralogi lava andesit terdiri dari plagioklas, piroksen, dan sedikit hornblende. Variasi pada lava basaltik memiliki komponen olivin yang cukup sering dijumpai. Satuan litologi keseluruhan adalah sebagai berikut:

1. Endapan Jatuhan Freatik Sindoro ( $\mathrm{Sjf})$ dengan fragmen andesit dari ukuran kerikil hingga berangkal yang berserakan tanpa kehadiran bom dengan struktur kerak roti atau yang sering disebut bom kerak roti (Gambar 6a).

2. Lava Andesit 9 Sindoro (S1 9) membentuk morfologi kubah yang tampak ke arah timur dan utara. Lava andesit 9 Sindoro merupakan lava hasil erupsi pusat.

3. Lava Andesit 8 Sindoro (S1 8) membentuk morfologi lereng yang tampak ke arah utara. Lava andesit 8 Sindoro merupakan lava hasil erupsi pusat. Lava berstruktur masif dan blocky.

4. Endapan Aliran Piroklastik 6 Sindoro (Sap 6) membentuk morfologi menyerupai punggungan, berasal dari erupsi pusat. Komposisi meliputi fragmen berupa bongkah andesit dan belum terkonsolidasi serta tidak dijumpai bom kerak roti. 


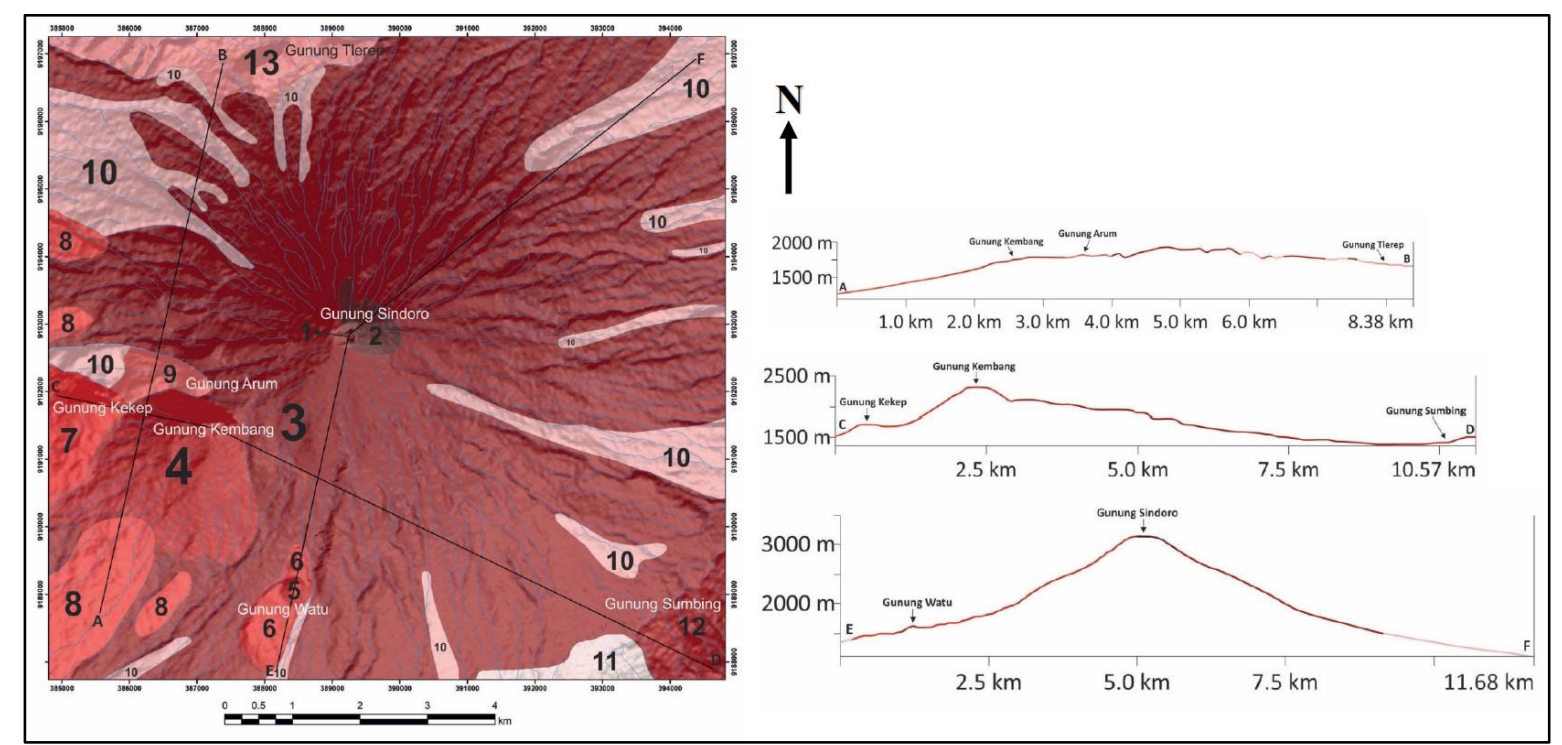

Gambar 2. Peta dan penampang geomorfologi daerah penelitian, menunjukan morfologi gunungapi strato dengan kerucut parasit di lerengnya

\begin{tabular}{|c|c|c|c|c|}
\hline \multicolumn{2}{|c|}{$\begin{array}{l}\text { BENTANG } \\
\text { ALAM }\end{array}$} & $\begin{array}{l}\text { SATUAN } \\
\text { GEOMORFOLOGI } \\
\text { SECARA GENESIS }\end{array}$ & $\begin{array}{l}\text { SIMBOL } \\
\text { WARNA }\end{array}$ & PEMERIAN \\
\hline \multirow{13}{*}{ 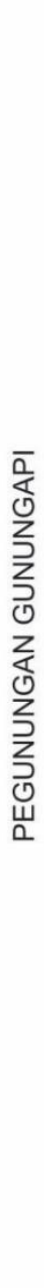 } & \multirow{11}{*}{$\begin{array}{l}\text { 음 } \\
\frac{0}{0} \\
\text { ஸे }\end{array}$} & $\begin{array}{l}\text { Kawah Erupsi } \\
\text { Jalatunda }\end{array}$ & & $\begin{array}{l}\text { Morfologi berupa kawah erupsi, kelerengan }<4^{\circ} \text {, elevasi } 3150 \text { mdpl, } \\
\text { disusun oleh endapan jatuhan freatik berupa fragmen andesit dari } \\
\text { ukuran kerikil hingga berangkal yang berserakan tanpa kehadiran bom } \\
\text { kerak roti. Merupakan bagian dari puncak gunungapi komposit (Khuluk } \\
\text { Sindoro). }\end{array}$ \\
\hline & & $\begin{array}{l}\text { Kubah Lava } \\
\text { Sindoro }\end{array}$ & & $\begin{array}{l}\text { Morfologi berupa kubah lava, kelerengan }<55^{\circ} \text {, elevasi antara } 2750- \\
3100 \text { mdpl, disusun oleh lava andesit. Merupakan bagian dari puncak } \\
\text { gunungapi komposit (Khuluk Sindoro). }\end{array}$ \\
\hline & & $\begin{array}{l}\text { Kerucut } \\
\text { Gunungapi } \\
\text { Sindoro }\end{array}$ & & $\begin{array}{l}\text { Morfologi berupa kerucut gunungapi dengan relief sedang-kasar, } \\
\text { kelerengan }<55^{\circ} \text {, elevasi antara } 1125-3100 \mathrm{mdpl} \text {, disusun oleh lava } \\
\text { andesit, lava basalt dan endapan piroklastik. Merupakan bagian dari } \\
\text { lereng gunungapi komposit (Khuluk Sindoro). }\end{array}$ \\
\hline & & $\begin{array}{l}\text { Kerucut } \\
\text { Gunungapi } \\
\text { Parasiter } \\
\text { Kembang }\end{array}$ & & $\begin{array}{l}\text { Morfologi berupa kerucut gunungapi dengan relief sedang-kasar, } \\
\text { kelerengan }<55^{\circ} \text {, elevasi antara } 1300-2320 \text { mdpl, disusun oleh lava } \\
\text { basalt. Merupakan bagian dari puncak dan lereng gunungapi parasiter } \\
\text { (Gumuk Kembang). }\end{array}$ \\
\hline & & $\begin{array}{c}\text { Kerucut } \\
\text { Gunungapi } \\
\text { Parasiter Watu }\end{array}$ & & $\begin{array}{l}\text { Morfologi berupa kerucut gunungapi dengan relief sedang, kelerengan } \\
<35^{\circ} \text {, elevasi antara } 1525-1575 \mathrm{mdpl} \text {, disusun oleh lava andesit. } \\
\text { Merupakan bagian dari puncak dan lereng gunungapi parasiter (Gumuk } \\
\text { Watu). }\end{array}$ \\
\hline & & $\begin{array}{l}\text { Punggungan } \\
\text { Aliran Lava Watu }\end{array}$ & 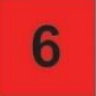 & $\begin{array}{l}\text { Morfologi berupa punggungan aliran lava dengan relief halus-sedang, } \\
\text { kelerengan }<16^{\circ} \text {, elevasi mencapai antara } 1325-1725 \mathrm{mdpl} \text {, disusun } \\
\text { oleh lava andesit. Merupakan bagian dari lereng gunungapi parasiter } \\
\text { (GumukWatu). }\end{array}$ \\
\hline & & $\begin{array}{l}\text { Kerucut } \\
\text { Gunungapi } \\
\text { Parasiter Kekep }\end{array}$ & & $\begin{array}{l}\text { Morfologi berupa kerucut gunungapi dengan relief sedang, kelerengan } \\
<35^{\circ} \text {, elevasi antara } 1550-1700 \text { mdpl, disusun oleh lava basalt. } \\
\text { Merupakan bagian dari puncak dan lereng gunungapi parasiter (Gumuk } \\
\text { Kekep). }\end{array}$ \\
\hline & & $\begin{array}{c}\text { Punggungan } \\
\text { Aliran Lava Kekep }\end{array}$ & 8 & $\begin{array}{l}\text { Morfologi berupa punggungan aliran lava dengan relief halus-sedang, } \\
\text { kelerengan }<35^{\circ} \text {, elevasi antara } 1100-1675 \text { mdpl, disusun oleh lava } \\
\text { basalt. Merupakan bagian dari lereng gunungapi parasiter (Gumuk } \\
\text { Kekep). }\end{array}$ \\
\hline & & $\begin{array}{l}\text { Kerucut } \\
\text { Gunungapi } \\
\text { Parasiter Arum }\end{array}$ & & $\begin{array}{l}\text { Morfologi berupa kerucut gunungapi dengan relief sedang-kasar, } \\
\text { kelerengan }<35^{\circ} \text {, elevasi antara } 1700-2150 \text { mdpl, disusun oleh lava } \\
\text { andesit. Merupakan bagian dari puncak dan lereng gunungapi parasiter } \\
\text { (Gumuk Watu). }\end{array}$ \\
\hline & & $\begin{array}{l}\text { Punggungan } \\
\text { Aliran Piroklastik } \\
\text { Sindoro }\end{array}$ & & $\begin{array}{l}\text { Morfologi berupa punggungan aliran piroklastik dengan relief halus- } \\
\text { kasar, kelerengan <35., elevasi antara } 1100-2200 \mathrm{mdpl} \text {, disusun oleh } \\
\text { endapan aliran piroklastik. Merupakan bagian dari lereng gunungapi } \\
\text { komposit (Khuluk Sindoro). }\end{array}$ \\
\hline & & $\begin{array}{l}\text { Dataran Antar- } \\
\text { Gunungapi } \\
\text { Sindoro dan } \\
\text { Sumbing }\end{array}$ & & $\begin{array}{l}\text { Morfologi berupa dataran antar gunungapi dengan relief halus, } \\
\text { kelerengan <4, elevasi } 1400 \text { mdpl, disusun oleh endapan jatuhan } \\
\text { piroklastik. Merupakan bagian dari dataran gunungapi komposit (Khuluk } \\
\text { Sindoro). }\end{array}$ \\
\hline & $\begin{array}{l}\text { 胥 } \\
\text { है } \\
\text { ज }\end{array}$ & $\begin{array}{l}\text { Kerucut } \\
\text { Gunungapi } \\
\text { Sumbing }\end{array}$ & & $\begin{array}{l}\text { Morfologi berupa kerucut gunungapi dengan relief halus-sedang, } \\
\text { kelerengan }<16^{\circ} \text {, elevasi antara } 1300-1500 \text { mdpl, disusun oleh endapan } \\
\text { jatuhan piroklastik. Merupakan bagian dari lereng gunungapi komposit } \\
\text { (Khuluk Sumbing). }\end{array}$ \\
\hline & 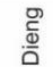 & $\begin{array}{c}\text { Kerucut } \\
\text { Gunungapi Tlerep }\end{array}$ & 2 & $\begin{array}{l}\text { Morfologi berupa kerucut gunungapi dengan relief halus-kasar, } \\
\text { kelerengan }<35^{\circ} \text {, elevasi antara } 1425-1825 \mathrm{mdpl} \text {, disusun oleh endapan } \\
\text { jatuhan piroklastik dan lava andesit. }\end{array}$ \\
\hline
\end{tabular}

Gambar 3. Satuan geomorfologi daerah Gunung Sindoro 
5. Endapan Aliran Piroklastik 5 Sindoro (Sap 5) membentuk morfologi menyerupai punggungan, berasal dari erupsi pusat. Komposisi meliputi fragmen berupa bom kerak roti bersusun andesit yang tertanam dalam matriks berupa abu (ash) dan belum terkonsolidasi (Gambar 6b).

6. Lava Andesit Watu (Wl) membentuk morfologi kerucut tampak pada Gunungapi Watu dan Gunungapi Arum secara berurutan lavanya mengalir ke selatan dan baratdaya membentuk punggungan dengan tepi yang curam sebagai penciri lava yang kental hasil erupsi samping.

7. Lava Basalt Kekep (KEl) membentuk morfologi kerucut tampak pada Gunungapi Kekep dan punggungan hasil aliran lava berarah relatif baratdaya dengan morfologi yang landai sebagai penciri lava yang lebih encer hasil erupsi samping (Gambar 7a, c).

8. Endapan Aliran Piroklastik 4 Sindoro (Sap 4) membentuk morfologi menyerupai punggungan yang merupakan aliran piroklastik hasil erupsi pusat. Komposisi meliputi fragmen berupa bom kerak roti bersusun andesit yang tertanam dalam matriks berupa abu (ash).

9. Endapan Aliran Piroklastik 3 Sindoro (Sap 3) membentuk morfologi menyerupai punggungan, hasil erupsi pusat. Di beberapa tempat, satuan ini ditemukan berasosiasi dengan endapan jatuhan piroklastik. Komposisi meliputi fragmen berupa bom kerak roti bersusun andesit yang tertanam dalam matriks berupa abu (ash).
10.Lava Andesit 7 Sindoro (S1 7) membentuk morfologi lereng yang tampak ke arah barat dan timur. Lava andesit 7 Sindoro merupakan lava hasil erupsi pusat. Di beberapa tempat tampak bagian permukaan yang membentuk breksi autoklastik sedangkan bagian tengah berstruktur masif.

11.Lava Andesit 6 Sindoro (Sl 6) membentuk morfologi lereng yang tampak ke arah baratdaya dan menabrak kerucut parasiter Kembang yang terbentuk lebih dahulu. Lava ini merupakan lava hasil erupsi pusat.

12.Lava Andesit 5 Sindoro (S1 5) membentuk morfologi lereng yang tampak ke arah timur dan timurlaut, hasil erupsi pusat. Lava ini menunjukkan bagian permukaan yang membentuk breksi autoklastik sedangkan bagian tengah menunjukkan struktur masif.

13.Lava Andesit 4 Sindoro (S1 4) membentuk morfologi lereng yang tampak ke arah barat dan tenggara, merupakan lava hasil erupsi pusat (Gambar 7b, d).

14.Endapan Jatuhan Piroklastik Sindoro (Sjp) membentuk morfologi lereng hingga dataran. Hasil erupsi pusat yang berasosiasi dengan endapan aliran piroklastik. Endapan ini memiliki warna kecoklatan dan ditemukan struktur sedimen berupa perlapisan bersusun normal, Komposisi meliputi fragmen berupa lapili bersusun andesit yang tertanam dalam matriks berupa abu (ash).

15.Lava Basalt Kembang (K1) membentuk morfologi kerucut tampak pada Gunungapi Kembang, hasil erupsi samping.

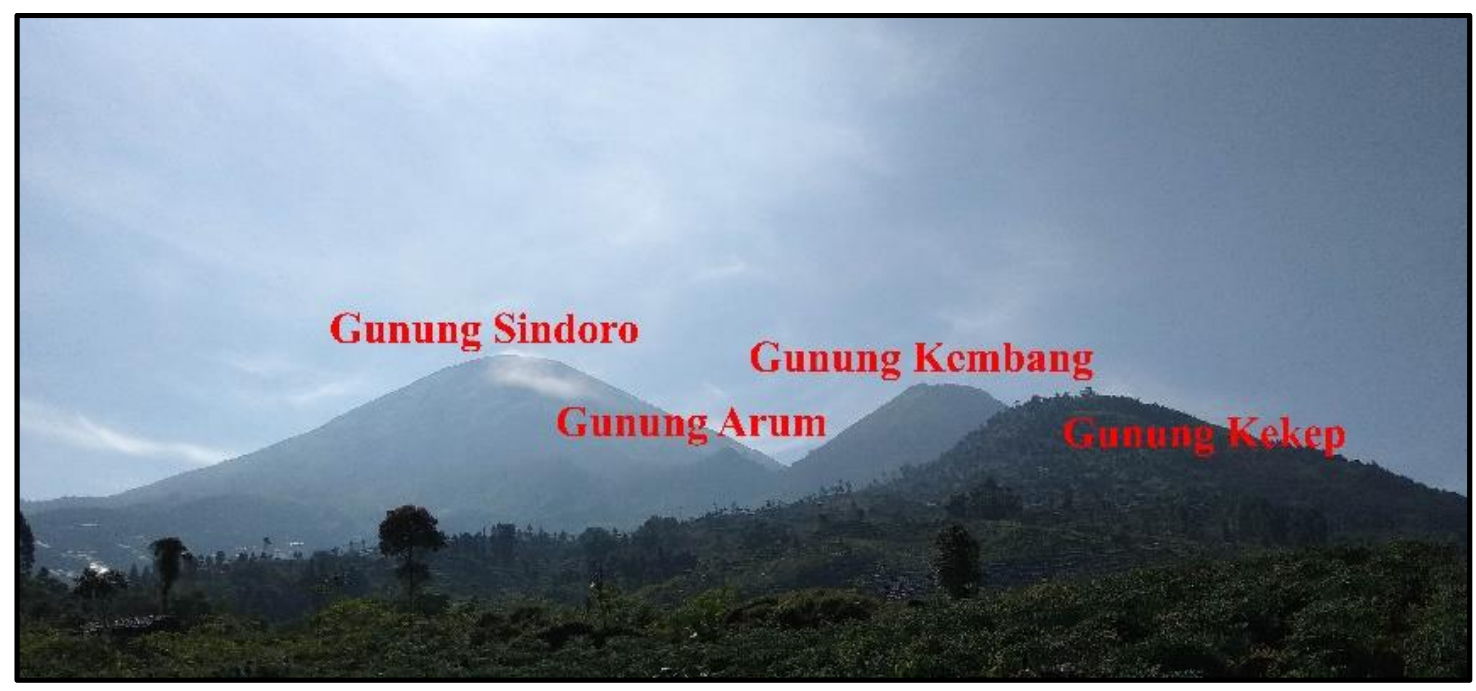

Gambar 4. Kenampakan Kerucut Gunung Sindoro beserta Kerucut Parasiter Kembang, Arum, dan Kekep pada arah $\mathrm{N} 100^{\circ}$ E dari Desa Kayugiyang 
16.Lava Andesit 3 Sindoro (S1 3) membentuk morfologi lereng yang tampak ke arah baratlaut. Lava andesit 3 Sindoro merupakan lava hasil erupsi pusat. Di beberapa tempat tampak lava yang membentuk breksi autoklastik sedangkan secara umum lava menunjukkan struktur massif.

17.Lava Andesit 2 Sindoro (S1 2) membentuk morfologi lereng yang tampak ke arah utara dan tenggara, hasil erupsi pusat. Singkapan yang ditemui umumnya dalam kondisi segar dan sering ditemukan berasosiasi dengan endapan jatuhan piroklastik.

18.Lava Basalt 1 Sindoro (Sl 1) membentuk morfologi lereng yang tampak ke arah timur dan timurlaut, merupakan lava hasil erupsi pusat.

19.Endapan Aliran Piroklastik 2 Sindoro (Sap 2) membentuk morfologi menyerupai punggungan. Endapan aliran piroklastik 2 Sindoro merupakan aliran piroklastik hasil erupsi pusat. Komposisi meliputi fragmen berupa bongkah andesit yang tertanam dalam matriks berupa abu (ash).

20.Endapan Aliran Piroklastik 1 Sindoro (Sap 1) membentuk morfologi menyerupai punggungan, hasil erupsi pusat. Di beberapa tempat, satuan ini ditemukan berasosiasi dengan endapan jatuhan piroklastik. Komposisi meliputi fragmen berupa bom skoria yang tertanam dalam matriks berupa abu (ash).

21.Produk Vulkanik Sumbing (SBv) membentuk morfologi lereng. Karakteristik memiliki struktur sedimen berupa perlapisan bersusun normal, sortasi menengah-baik, kemas tertutup, bentuk butir membundar tanggung - menyudut tanggung. Komposisi meliputi fragmen berupa lapili bersusun andesit yang tertanam dalam matriks berupa abu (ash)

22.Produk Vulkanik Dieng (Dv) membentuk morfologi lereng. Endapan jatuhan piroklastik yang ditemui umumnya memiliki warna kecoklatan, ditemukan struktur sedimen berupa perlapisan bersusun normal, sortasi menengah-baik, kemas tertutup, bentuk butir membundar tanggung menyudut tanggung. Komposisi meliputi fragmen berupa lapili bersusun andesit yang tertanam dalam matriks berupa abu (ash).

\section{Karakter Letusan Gunungapi Sindoro di Daerah Penelitian}

Karakter letusan suatu gunungapi dapat diketahui dari sejarah geologi gunungapi dan endapan/batuan hasil letusannya. Secara umum, litologi yang ditemukan di daerah penelitian meliputi lava dan endapan klastika gunungapi. Lava yang ditemukan dapat dibedakan menjadi dua kelompok yaitu kelompok basalt dan kelompok andesit. Kedua kelompok tersebut ditemukan dalam bentuk aliran lava dan intrusi. Berdasarkan data stratigrafi batuan gunungapi, dapat diketahui bahwa karakter letusan Gunungapi Sindoro didominasi oleh letusan tipe strombolian.

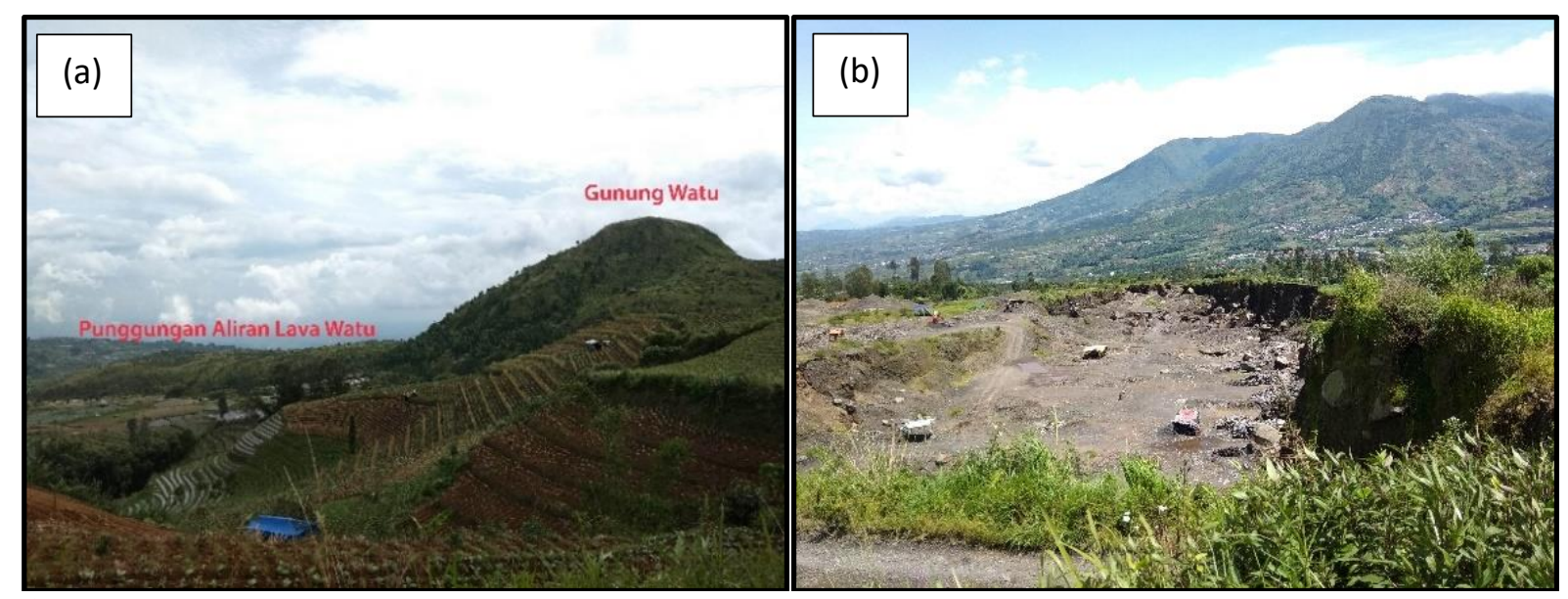

Gambar 5. (a) Kenampakan Punggungan Aliran Lava Watu beserta Gunungapi Watu di lapangan. Gambar diambil di Desa Candiyasan, arah kamera N250 E. (b) Kenampakan Punggungan Aliran Piroklastik Sindoro dari Desa Tambi, arah kamera $\mathrm{N} 120^{\circ} \mathrm{E}$. 


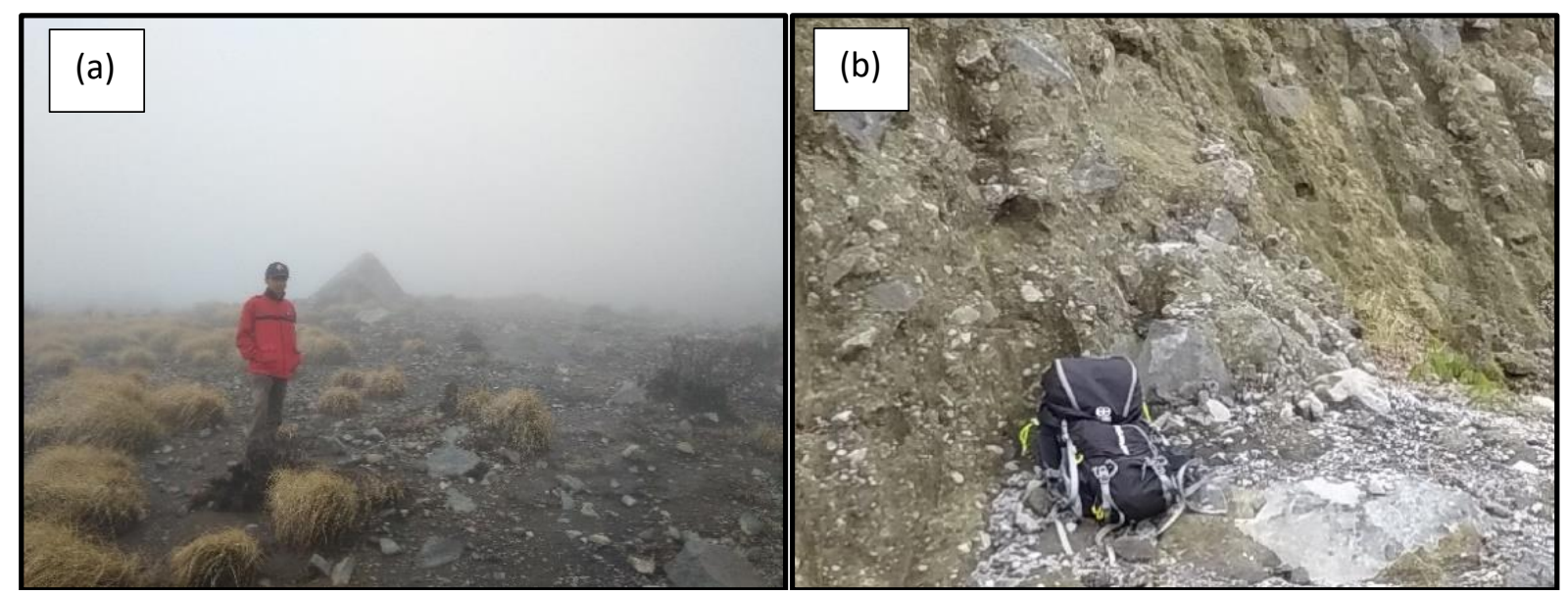

Gambar 6. (a) Kenampakan endapan jatuhan freatik Sindoro di puncak dengan elevasi 3.140 mdpl, (b) Singkapan endapan aliran piroklastik 5 Sindoro di Desa Candimulyo.

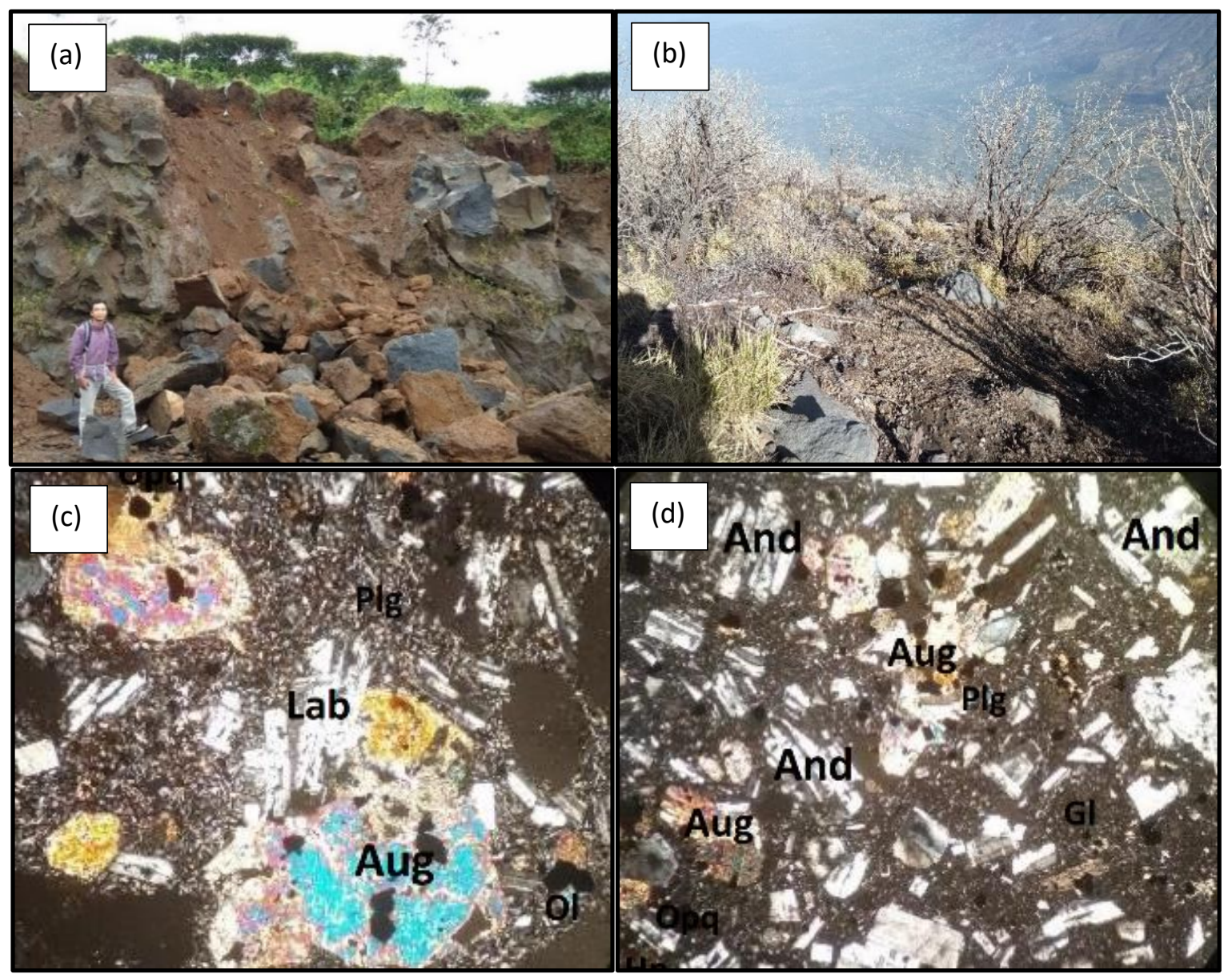

Gambar 7. (a) Singkapan lava basalt Kekep di Desa Tlogojati, (b) Singkapan lava andesit 4 Sindoro. di sekitar puncak Gunungapi Sindoro. (c) Kenampakan petrografi lava basalt Kekep terdiri dari augit (aug), plagioklas (plg, lab), olivin (ol) dan massa dasar gelasan. (d) Petrografi lava andesit Sindoro terdiri dari plagioklas andesin (and), augit (aug), pada massa dasar gelasan (gl). 

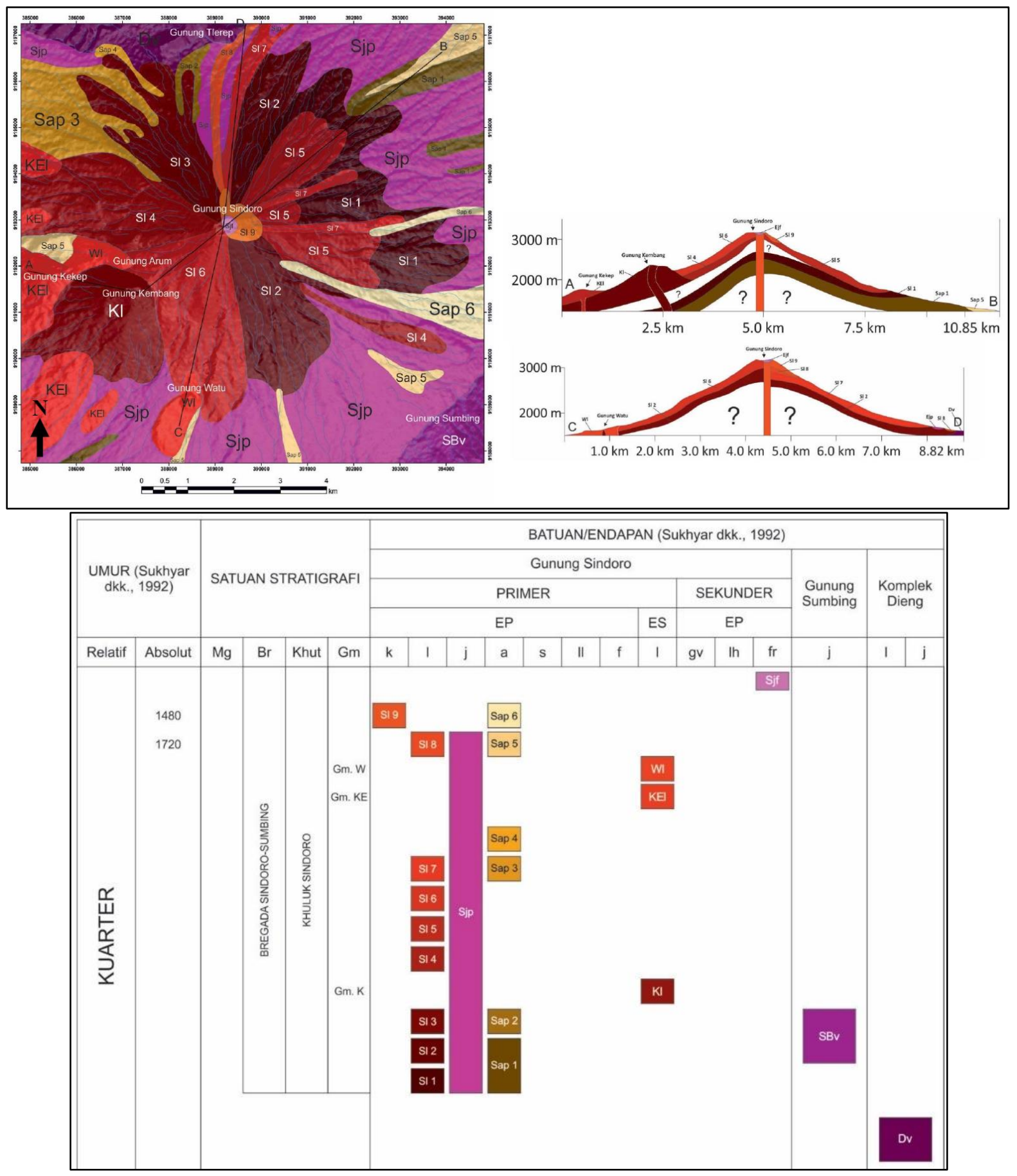

Gambar 8. Peta geologi dan vulkanostratigrafi daerah Gunung Sindoro berdasarkan interpretasi citra dan pemetaan geologi, data umur absolut berdasar Sukhyar dkk (1992)

\section{PEMBAHASAN}

\section{Fasies Vulkanik Daerah Penelitian}

Pemetaan fasies vulkanik di daerah penelitian didasarkan pada penginderaan jarak jauh meliputi analisis citra satelit serta pengamatan langsung di lapangan meliputi geomorfologi dan stratigrafi batuan gunungapi. Berdasarkan model fasies dari Bogie dan MacKenzie (1996), sistem Gunungapi
Sindoro dapat dibagi menjadi tiga fasies yaitu fasies sentral, proksimal, dan medial dari beberapa pusat erupsi (Gambar 10).

\section{Sistem Gunungapi Sindoro}

1. Fasies Sentral Sindoro (FSS) tersebar di bagian puncak Gunungapi Sindoro yang tersusun atas kubah lava dan endapan jatuhan freatik. 


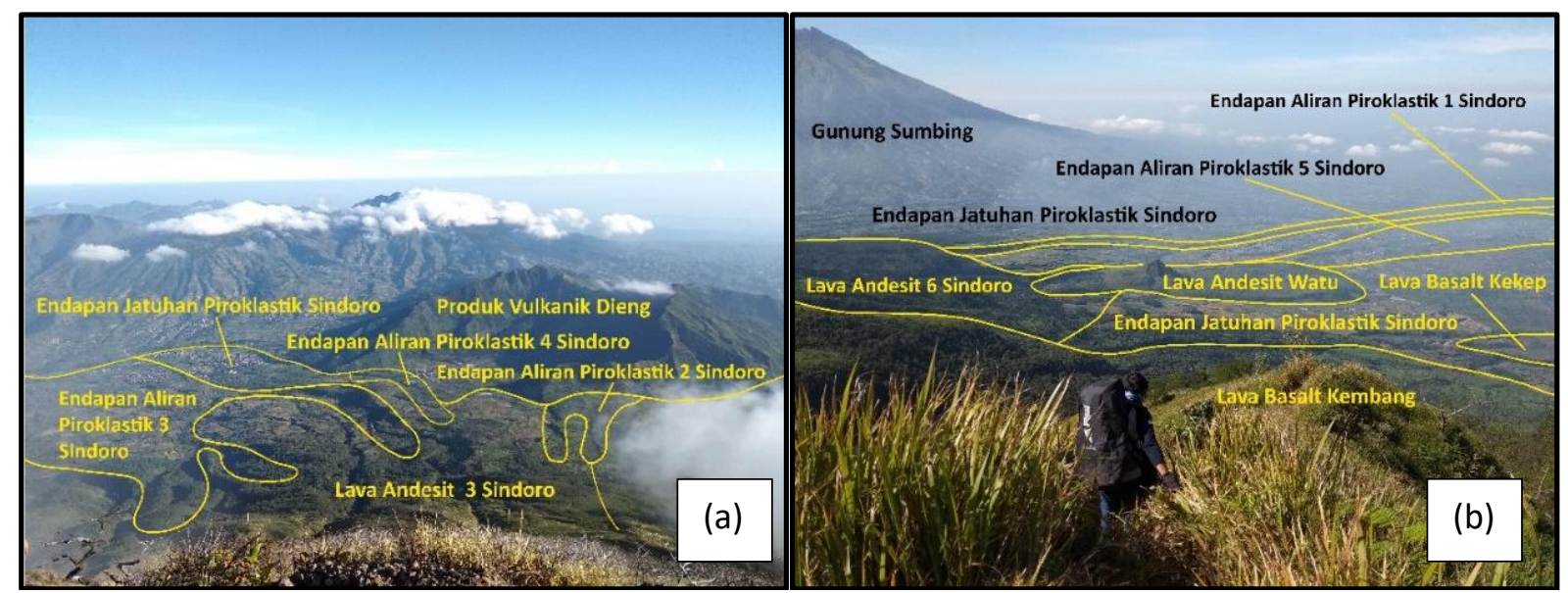

Gambar 9. (a) Persebaran satuan litologi bagian baratlaut Gunung Sindoro, terlihat dari lereng atas jalur pendakian Gunungapi Sindoro via Sigedang. (b) Bagian baratdaya Gunung Sindoro yang didominasi lava, terlihat dari puncak Gunung Kembang.

2. Fasies Proksimal Sindoro (FPS) sebagian besar disusun oleh aliran lava hasil erupsi pusat Gunungapi Sindoro yang tersebar ke segala arah dan sedikit endapan klastika gunungapi seperti endapan aliran piroklastik dan endapan jatuhan piroklastik. Fasies ini ditemukan pada morfologi lereng atas Gunungapi Sindoro.

3. Fasies Medial Sindoro (FMS) didominasi oleh endapan klastika gunungapi seperti endapan aliran piroklastik dan endapan jatuhan piroklastik. Endapan yang menyusun fasies ini merupakan produk Gunungapi Sindoro yang tersebar di bagian lereng bawah.

\section{Sistem Gunungapi Parasiter Kembang}

1. Fasies Sentral Kembang (FSK) berupa intrusi lava yang membentuk Kerucut Gunungapi Parasiter Kembang yang merupakan erupsi samping dari Gunungapi Sindoro. Fasies ini tersebar di bagian puncak Gunungapi Kembang.

2. Fasies Proksimal Kembang (FPK) tersusun atas aliran lava hasil erupsi samping dari Gunungapi Sindoro yang tampak menyebar ke arah baratdaya. Fasies ini ditemukan pada morfologi lereng atas Gunungapi Kembang.

\section{Sistem Gunungapi Parasiter Kekep}

1. Fasies Sentral Kekep (FSKE) sebagian besar terdiri atas intrusi lava yang tersebar di bagian barat dan baratdaya daerah penelitian dengan penamaan fasies diambil dari kerucut tertinggi yaitu Kerucut Gunungapi Parasiter Kekep yang merupakan erupsi samping dari Gunungapi Sindoro. Di daerah penelitian terdapat lima fasies sentral Kekep didasarkan pada karakteristik batuan yang ditemui di lapangan berupa lava basalt.

2. Fasies Proksimal Kekep (FPKE) tersusun dari aliran lava hasil erupsi samping Gunungapi Sindoro yang tampak menyebar ke arah barat dan baratdaya. Fasies ini ditemukan pada morfologi lereng terutama pada Gunungapi Kekep dan morfologi lainnya yang memiliki karakteristik yang sama dengan Gunungapi Kekep.

\section{Sistem Gunungapi Parasiter Watu}

1. Fasies Sentral Watu (FSW) terdiri dari intrusi lava produk Gunungapi Watu dan Gunungapi Arum yang membentuk kerucut gunungapi parasiter di sisi selatan dan barat daerah penelitian dan merupakan hasil erupsi samping dari Gunungapi Sindoro. Di daerah penelitian terdapat tiga fasies sentral Watu didasarkan pada karakateristik batuan yang ditemui di lapangan berupa lava andesit.

2. Fasies Proksimal Watu (FPW) tersusun dari aliran lava hasil erupsi samping Gunungapi Sindoro yang tampak menyebar ke selatan dan barat. Fasies ini cirikan dengan morfologi berupa Punggungan Aliran Lava Watu serta Kerucut Gunungapi Parasiter Arum.

\section{KESIMPULAN}

Secara genetiknya, morfologi bentang alam gunungapi daerah penelitian dapat dibagi menjadi 13 satuan geomorfologi. Stratigrafi daerah penelitian dapat dibagi menjadi 22 satuan 


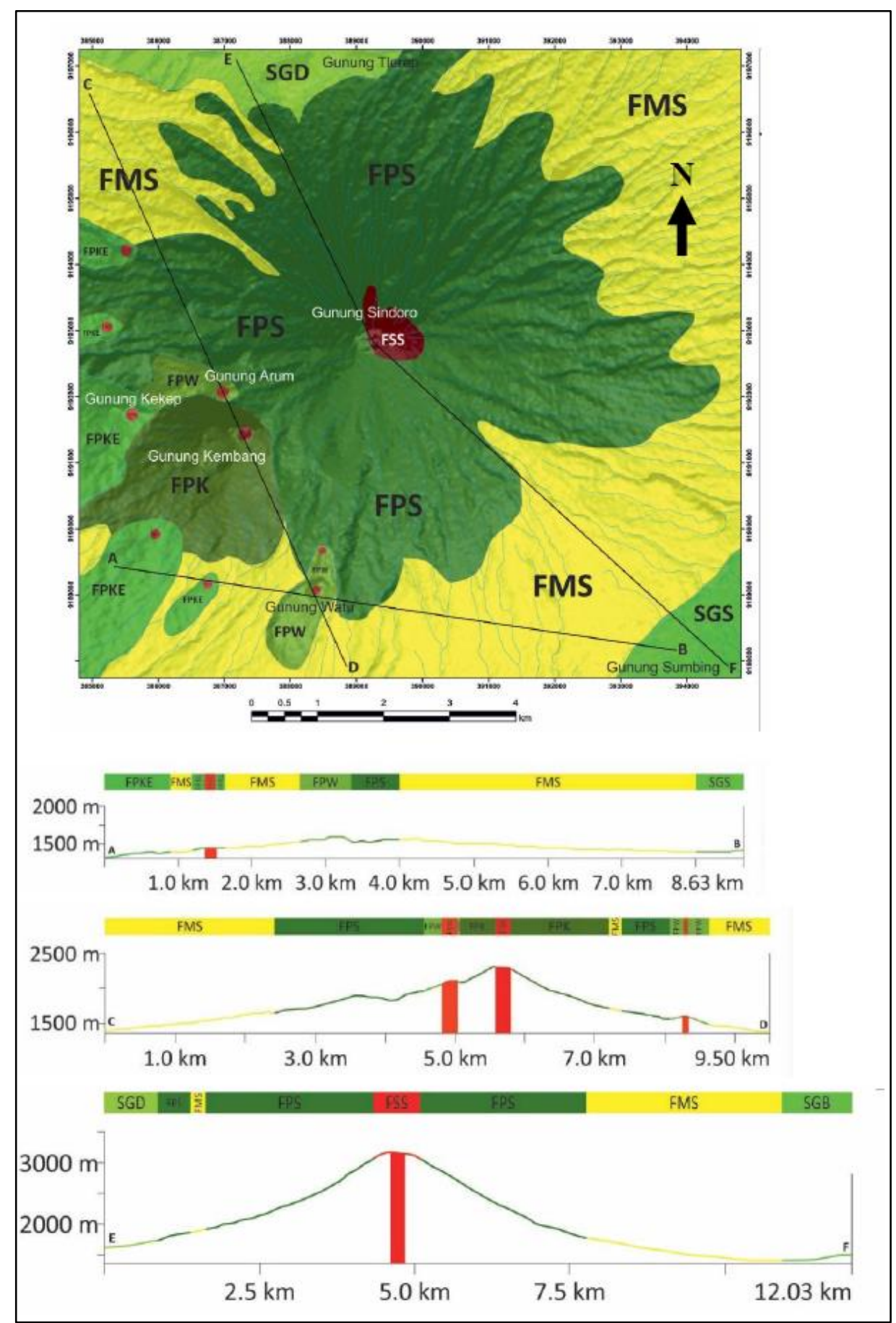

Gambar 10. Fasies vulkanik Gunung Sindoro berdasarkan integrasi aspek geomorfologi dan stratigrafi

batuan yang didasarkan pada pengamatan langsung di lapangan dan interpretasi citra Landsat serta DEM. Karakter letusan Gunung Sindoro dapat dilihat dari morfologi dan stratigrafi yang merupakan produk hasil aktivitasnya, yaitu karakter letusan Strombolian dengan produk utama berselingan antara lava andesit-basalt dan endapan piroklastik.
Sebagai gunungapi komposit strato, fasies Gunung Sindoro dibagi berdasarkan keberadaan pusat erupsinya. Fasies vulkanik di daerah penelitian dapat dibagi menjadi tiga fasies yaitu fasies sentral, proksimal, dan medial dari beberapa pusat erupsi yaitu Gunungapi utama Sindoro, Gunungapi Parasiter Kembang, Gunungapi Parasiter Kekep, dan Gunungapi Parasiter Watu. 


\section{UCAPAN TERIMA KASIH}

Penulis berterima kasih kepada A. Syaifudin Abdul Jabar A., Ariya Magga V. B., Syam Lingga W., Muzaki dan GADAPALA Adventure Purbalingga yang telah membantu dalam kegiatan pemetaan di Gunungapi Sindoro.

\section{DAFTAR PUSTAKA}

Atmadja, R.S., Maury, R.C., Bellon, H., Pringgoprawiro, H., Polve, M., dan Priadi, B., 1994, Tertiary magmatic belts in Java, Journal of Southeast Asian Earth Science, 9(1/2), 1327.

Bogie, I. dan Mackenzie, K.M., 1998, The application of a volcanic facies models to an andesitic stratovolcano hosted geothermal system at Wayang Windu, Java, Indonesia, Prosiding $20^{\text {th }}$ NZ Geothermal Workshop, 265-276.

Brahmantyo, B., dan Bandono, 2006, Klasifikasi Bentuk Muka Bumi (Landform) untuk Pemetaan Geomorfologi pada Skala 1:25.000 dan Aplikasinya untuk Penataan Ruang, Jurnal Geoaplika, 1(2), 71-78.

Ikatan Ahli Geologi Indonesia, 1996, Sandi Stratigrafi Indonesia.

Pusat Vulkanologi dan Mitigasi Bencana Geologi, 2014, Gunung Sundoro, Diambil dari http://www.vsi.esdm.go.id/index.php/gunung api/data-dasar-gunungapi/534-g-sundoro.

Sukhyar, R., Sumartadipura, N.S., dan Erfan, R.D., 1992, Peta Geologi Gunungapi Sundoro, Jawa Tengah skala 1:50.000, Direktorat Vulkanologi: Bandung.

Van Bemmelen, R.W., 1970, The Geology of Indonesia, 1A, Martinus Nijhoff, the Hague. 